\title{
Academic excellence in the age of information technology
}

\author{
Alla I. Varlamova ${ }^{1, *}$ \\ ${ }^{1}$ SFU under the Government of the Russian Federation, Foreign Languages Department, Moscow, Russia
}

\begin{abstract}
This article presents the results of the author's analysis of academic excellence in times of globalization and information technology. The author considers the problem in terms of the creation and the success of the research universities, highlights the main features of the world's leading universities, identifies potential threats of creation in developing countries and countries with transition economies, and places emphasis on particular criteria for the top world rankings
\end{abstract}

Is it possible to create a world-class university from scratch? In today's rapid pace of economic development many countries have made, and not in vain, attempts to create research universities of a world class in order to achieve academic excellence. These universities are to become the central institutions of the age of knowledge economy and their successful creation and development will help the developing countries in the nearest future.

What is meant by the term "academic excellence"? In our view, this is that characteristic, which extends the capabilities of faculty, staff and administrators in implementing the goals of the University. These objectives must approve the University's commitment to best practices in teaching and learning, science and creativity. Moreover, the implementation of these objectives should contribute to the growth and development of teachers and students, their extensive research activities.

Education, namely, higher education is a way to empower people and develop a country. Formation of knowledge at the moment substitutes ownership of capital assets and labor productivity as the main source of growth and prosperity. Innovation is seen as a development mantra. Awareness of this fact is so significant that many countries are fighting for the right to create research universities. Formation of knowledge requires intensive work on creation of a vast network of scientists involved in the search for new knowledge. Thus, modern research university should be an ideal place to find new ideas in the spirit of free research.

Throughout the human history universities were among the most important institutions that arise, develop and successfully survived up to present days. Over the centuries, of course, there have been some changes in the structure of universities. In the era of Plato and Aristotle universities were centers for dialogue and discussions to understand the destiny of men and their place in the world. The dominant paradigm was abstract thinking in philosophy and mathematics. Universities, which formed in the days of Pierre Abelard (French medieval philosopher), were regarded as a theocratic space, where religious issues were discussed. The concept of universities as research institutions dates back to Germany where new universities were originated in the $19^{\text {th }}$ century since the arrival of the Industrial Revolution with its new ideas of development. This required carrying out some empirical researches in the laboratory prior to the introduction of new ideas into production. Superiority of research over teaching activities was established in the days of Humboldt, reformer of secondary education in Prussia, the founder of the University in Berlin in 1809, when there was a constant "thirst" for knowledge. A distinctive feature of the modern university at that time was a substantial public funding to support researches.

Now let us have a look at research universities and their particularities. Great attention is paid to specializations of individual disciplines, as the division of science into disciplines and sub-disciplines gives a better view of the overall picture of the world in the modern research university. However, increasing understanding of the problems of the $21^{\text {st }}$ century requires a holistic view on things. Today, new knowledge generated at the boundaries of existing disciplines, and the mutual enrichment of achievements takes place in various ways. There is a need to relate researches and the needs of society - and this is the dominant paradigm of this type of universities. Is the structure of a modern research university is flexible enough to provide the appropriate multi-disciplinary knowledge and coordinate successfully to bring together an education and the needs of society - this question still demands the confirmation. And the world today is a place, which is looking forward to another tectonic shift in our understanding of the purpose of universities.

We would like to make a point of developing and transition economies in order to find the positive 
moments that could be used to create research universities in Russia.

The main objective of the creation and successful development of research universities in these countries is the problem of determining the mechanisms that will allow them on a par with leading academic institutions to participate successfully in the search for new knowledge. Created research universities, for their part, will have to provide advanced education for scientists, politicians, and the employed in the public and private sectors - all those who involved in the development of their country in the globalized economies of the $21^{\text {st }}$ century. In addition to its contribution to the economic development these universities should play a key social role, acting as cultural institutions and intellectual property accumulation centers of the country.

Thus, it is supposed that the positive contribution of higher education to the development of economies can be seen not only in countries where people primarily live with middle and high incomes, but also in those countries where the majority of the population has lowincome. The development of higher education in these countries will help become more competitive in the global market through the availability of more educated, productive and flexible workforce, as well as through the creation, development and application of new ideas and technologies.

Undoubtedly, the availability of qualified teachers and technicians, as well as the implementation of advanced knowledge can help developing countries achieve the Millennium Development Goals, and build that type of higher education, which will help reduce poverty. Progress in the field of agriculture, health, and environmental protection cannot be achieved without highly qualified specialists. Similarly, higher education accessible for everyone cannot exist without teachersprofessionals.

The study has recently been carried out about how to accelerate economic growth in the poorest African countries. As a result of this study the crucial role of higher education in this matter was confirmed [17]. The report, in particular, has emphasized that the key to the success of a country in a globalized world is mainly in how well a nation can absorb accumulated world knowledge to obtain a comparative advantage in areas with high growth potential, as well as how advanced technology can be used to deal with emerging threats. It is also emphasized that higher education institutions in African countries, which use cutting-edge technologies to undertake research projects of applied nature, can and should play a key role in the training of highly qualified personnel with appropriate knowledge for the development of new technologies that will further help diversify their products. Moreover, higher education is a key factor in the development of innovative technologies in the production of new materials, development of new energy sources and the development of crops, which, in turn, will help reduce poverty, ensure food security and improve public health.

In the frame of higher education, research universities play a vital role in training of high-level professionals who are required for the country's economy, as well as to generate new knowledge which can be used in the development of the national innovation system [16]. For example, a recent study has confirmed the fact that research universities and institutions which promote scientific progress in the field of biotechnology is much more efficient than the various companies and firms [5]. In this context, a priority for many countries is to ensure that their top universities are actually operating at the best intellectual and scientific levels.

Some researchers are trying to identify the main features that distinguish leading research universities from other institutions of higher education. Among others, for example, are the following:

- A highly qualified staff;

- Excellent research results;

- High quality of teaching and learning;

- A high level of public and private financing;

- The presence of foreign and talented students;

- Teaching freedom (teachers' personal creative freedom in teaching and research work and necessity to take into account the opinion of each scientist by university administration; freedom of higher education institutions, mostly private, in the field of selection of principles and methods of the educational process);

- Well-defined independent governance structure; The presence of great opportunities for teaching, research, management and students' life [4], [8], [11], [12].

Recognizing the role of research universities in fastgrowing regions of Asia and Latin America, some scientists have considered the development of these institutions in seven countries, with a focus on what is needed to create research universities in difficult environment [3].

Moreover, in order to understand how to create research universities, a more convenient definition has been given. It has proved that among the expected results of the functioning of these universities are:

- Demanded graduates;

- Advanced research and development;

- Functional knowledge and technology transfer.

The achievement of such results is impossible without an additional set of the following factors: a) a large concentration of talented people (students and faculty members); b) a sufficient amount of resources for education and advanced research; c) favorable governance organization that promotes leadership, strategic thinking, innovation and mobility. All these features enable the university to make decisions and manage resources without interference from various bureaucracies. The successful interaction of the above factors provides research universities with an advantage which distinguishes them apart from institutions of higher education. These researchers have also defined three basic approaches of creating. The first is to upgrade the existing universities that have the potential to reach new results. The second way - is a merge of several universities with the aim of converting them into a new university with great development potential. Finally, a third approach - the creation of a research university from scratch [14]. 
What criteria can be taken into account by international agencies, which lead the ranking of universities? We have chosen three of the most popular ratings.

1. The Academic Ranking of World Universities (ARWU), prepared by Shanghai Jiao Tong University. This academic ranking analyzes three thousand universities, from which the best five hundred are selected. The selection criteria are the following: - Quality of education: university graduates who were awarded the Nobel Prize and Fields Medal Award-10\%;

- The quality of the University:

a) staff of the university, who was winning Nobel prizes and Fields Medals - 20\%;

b) highly cited researchers in 21 subjects - 20\%; - The results of research: $20 \%$;

a) scientific papers published in Nature and Science -

b) publications, indexed in Science Citation Indexexpanded, available as part of Web of Science and in Social Science Citation Index - 20\%;

- per capita performance $-10 \%$ [2].

Thus, we see that the Shanghai ranking compares the research activities of the universities. Higher education institutions are considered as research organizations, and not as organizations providing educational services to the society. Criteria related to the number of researchers and the number of scientific publications, which is associated with the scientific activities, have the greatest significance. Thus, the rating would be higher if there will be more publications in prestigious journals, more citations and more Nobel laureates.

If we look at the rating of 2015 and try to find our Russian universities, unfortunately we can see that the first university - Moscow State University (Lomonosov University) - is only on the $86^{\text {th }}$ place. This is followed by St. Petersburg State University lagging by 245 positions. Much to our regret, we have not found a single Russian university among the top 500 universities in addition to the two mentioned above [1].

2. The Higher Education Evaluation and Accreditation Council of Taiwan - HEEACT. Five hundred universities are taken into account in this ranking. The following positions are criteria for university evaluation:

- Research activities: a) the number of articles have written over the past eleven years - $10 \%$; b) number of articles have written in the current year - $10 \%$;

- the number of citations in the last eleven years $10 \%$

- the number of citations in the last two years - $10 \%$;

- the average number of citations in the last eleven years - $10 \%$;

- H-index over the past two years - 20\%;

- The number of the most cited publications - $15 \%$;

- The number of articles written in the current year in the most cited journals - $15 \%$ [6].

3. Of course, at the age of information technology great importance is given to the virtual space, so Spanish Internet sites - Webometrics- are highly valued and rated. It drafts radically different rankings, for example, from the Shanghai ranking. This ranking compares the official websites of higher education institutions and takes into account the following four positions:

- Size - number of pages of the official website of the university, found with the help of the four search sites (Google, Yahoo, Live Search, Exalead) - 25\%;

- Visibility - the number of unique external links to the pages of the site $-50 \%$;

- Rich Files - the number of "valuable" files (Adobe Acrobat - .pdf; Adobe Postscript - .ps; Microsoft Word .doc; Microsoft PowerPoint - .ppt), posted on the site $12.5 \%$;

- Scholar - Online citation of scientific publications $12.5 \%$ [15].

If we have a look at Russian universities in this ranking, we would like to highlight the first ten ones:

1. Lomonosov Moscow State University - 138 place.

2. Saint Petersburg State University - 458 place.

3. Novosibirsk State University - 614 place.

4. National Nuclear Research University (Moscow State Engineering Physics Institute) - 859 place.

5. Moscow Institute of Physics and Technology - 970 place.

6. Ural Federal University - 978 place.

7. ITMO University - 1001 place.

8. Saint Petersburg State Polytechnic University 1008 place.

9. Tomsk State University - 1055 place.

10. Kazan (Volga Region) Federal University - 1181 place [13].

Now a few words about the problems that may be encountered by research universities.

Firstly, it is, of course, funding. The key to the success is an appropriate and permanent funding. Research universities may have difficulties creating their own fund, attracting funds from potential donors, the sale of intellectual products and consulting services, as well as charging tuition fees. For example, public research universities do not have the right to establish tuition fees above a certain amount, despite the fact that students are able and willing to pay more for high quality education in prestigious institutions. Of course, in terms of the global economic crisis, countries may have different capabilities for creation and successful financial support of research universities. From this point of view, the East Asian countries are better able to cope with this task than their eastern neighbors. For example, India has increased its investment in higher education to $31 \%$ since 2010, while China continues to finance substantially their leading universities.

The second problem is self-sufficiency. Universities have a great responsibility for the results of their work, therefore, in our opinion, they also should have greater autonomy in decision-making on management issues. From this point of view, most public universities are now in a weak position having much accountability and compliance with certain bureaucratic rules.

The third problem is attracting the best teachers and talented students. Human resources area is one of the most pressing problems for developing of research universities. Often, the salary in the private sector is much higher than in the field of education. There is also the threat of taping highly skilled professionals abroad. 
Prospective students also tend to choose the best scholarship, a prestigious institution and the best learning environment.

Next possible threat is the possibility of transferring public universities into private ones. Most research universities are state-owned. When public funding decreases, it is possible for a successfully functioning university to be taken over by private institutions in order to obtain benefits. This process is detrimental to science and the universities, as they carry out fundamental research in the strategically important spheres of the country [7].

The last potential problem, oddly enough, is globalization. According to some scientists, the process of globalization has both positive and negative impact on universities [9], [10].

Thanks to research universities, countries get an opportunity to participate in international scientific and educational world. At a point of information technology and global web Internet people may have enormous benefits from the process of knowledge globalization. Moreover, research universities are the only ones who are connected to the global scientific network in many countries. On the other hand, globalization is a problem in the sense that the best authors of the best publications of the world's leading magazines are often hunted by more prestigious universities. Thus, there is a direct relation of key international journals to their research criteria.

Consequently, the age of information technology for the higher education sector is regarded both as positive and negative aspects. But the current global trend is the tendency to create research universities, as most of the countries want to be actively involved in the world of science, to conduct research and development along with the world's leading universities. So, it is vital to create and develop research universities actively in order to be able to compete in the global knowledge market.

\section{References}

1. Academic Ranking of World Universities Available online: URL http://www.arwu.org/ARWU2010.jsp (accessed 08.02.2016)

2. Academic ranking of world universities Available online:

URL http://www.shanghairanking.com/ru/ARWU2015.ht $\mathrm{ml}$ (accessed 08.02.2016)

3. A.G. Philip, and J. Balan, World Class Worldwide: Transforming Research Universities in Asia and Latin America (Johns Hopkins University Press, Baltimore, 2007)
4. A.G. Philip, Academe, 90 (1), 20-23 (2004) Available online: URL http://www.aaup.org/AAUP/pubsres/academe/2004/ JF/Feat/altb.htm (accessed 08.02.2016)

5. C. Cookson, Financial Times Europe, May 6 (2007)

6. Higher Education Evaluation and Accreditation Council of Taiwan Available online: URL http://ranking.heeact.edu.tw/en-us/2010/TOP/100 (accessed 08.02.2016)

7. G.L. Roger, Knowledge and Money: Research Universities and the Paradox of the Marketplace (Stanford University Press, Stanford, CA 2004)

8. K.K. Aik, R. Shukor, O. Hassan, Z. Saleh, A. Hamzah, and R.Hj.Ismail, College Student Journal, 39 (4), 765-68 (2005) Available online: URL http://findarticles.com/p/articles/mi_mOFCR/is_4_3 9/ai_n16123684 (accessed 08.02.2016)

9. J. Knight, Higher Education in Turmoil: The Changing World of Internationalization (Sense, Rotterdam, The Netherlands, 2008)

10. S.Marginson, M. van der Wende, OECD, 2, 17-62 (2009)

11. J. Niland, On Line Opinion, February 3 (2000) Available online: URL http://www.onlineopinion.com.au/view.asp?article= 997 (accessed 08.02.2016)

12. J. Niland, J. Sadlak, N. C. Liu, UNESCO-CEPES, 61-71 (2007)

13. Ranking Web of Universities Available online: URL http://www.webometrics.info/en/Europe/Russian \%2 0Federation (accessed 08.02.2016)

14. J. Salmi, The Challenge of Establishing WorldClass Universities (World Bank, Washington, 2009)

15. Webometrics Available online: URL http://www.webometrics.info/en (accessed 08.02.2016)

16. World Bank. Constructing Knowledge Societies: New Challenges for Tertiary Education (World Bank, Washington, 2002)

17. World Bank. Accelerating Catch-up: Tertiary Education for Growth in Sub-Saharan Africa (World Bank, Washington, DC, 2008) 